\title{
Regulation of the renal proximal tubule second sodium pump by angiotensins
}

C. Caruso-Neves,

L.B.A. Rangel, L.S. Lara and A.G. Lopes
Instituto de Biofísica Carlos Chagas Filho, Universidade Federal do Rio de Janeiro, Rio de Janeiro, RJ, Brasil

\section{Correspondence \\ A.G. Lopes \\ Instituto de Biofísica \\ Carlos Chagas Filho, UFRJ \\ CCS, Bloco G \\ 21949-900 Rio de Janeiro, RJ \\ Brasil \\ Fax: + 55-21-280-8193 \\ E-mail: agilopes@chagas.biof.ufr.br \\ The authors received the "Young \\ Talent in Life-Sciences-2000" \\ award for this article from the \\ Brazilian Society of Biochemistry \\ and Molecular Biology and Amersham \\ Pharmacia Biotech. \\ Research supported by PADCT, PRONEX, CNPq, FINEP, Fundação Universitária José Bonifácio (FUJB), FAPERJ and FAPESP.}

Received February 20, 2001 Accepted June 12, 2001

\section{Abstract}

For several years it was believed that angiotensin II (Ang II) alone mediated the effects of the renin-angiotensin system. However, it has been observed that other peptides of this system, such as angiotensin(1-7) (Ang-(1-7)), present biological activity. The effect of Ang II and Ang-(1-7) on renal sodium excretion has been associated, at least in part, with modulation of proximal tubule sodium reabsorption. In the present review, we discuss the evidence for the involvement of $\mathrm{Na}^{+}$ATPase, called the second sodium pump, as a target for the actions of these compounds in the regulation of proximal tubule sodium reabsorption.

\section{The role of the renin-angiotensin system in extracellular volume regulation}

Extracellular fluid volume depletion leads to the activation of several mechanisms involved in the conservation of water and electrolytes and in body fluid and arterial pressure homeostasis $(1,2)$. In this context, the renin-angiotensin system (RAS) plays a crucial role in the regulation of extracellular volume and blood pressure (3).

The RAS is activated by the release of renin, an aspartyl-protease, from renal juxtaglomerular cells during hypovolemic and hypotensive states $(4,5)$. This process is controlled basically by three pathways: a) macula densa, b) intrarenal baroreceptor, and c) Badrenergic receptor. The macula densa pathway is sensitive to the $\mathrm{NaCl}$ flux in the cortical thick ascending limb of Henle's loop (macula densa). Decreases in $\mathrm{NaCl}$ flux stimulate renin release and increases in $\mathrm{NaCl}$ flux across the macula densa result in renin inhibition. The second intrarenal mechanism controlling renin release is sensitive to variations in blood pressure in the preglomerular vessels where the increase or decrease in blood pressure inhibits or stimulates renin release, respectively. The latter mechanism involves the release of norepinephrine from postganglionic sympathetic nerve terminals, and activation of $\beta$-adrenoreceptors on juxtaglomerular cells enhances renin secretion.

Angiotensinogen hydrolysis by renin forms the decapeptide angiotensin I (Ang I), which is the substrate for the formation of other angiotensin peptides (5). During several years, it was believed that the effects of the RAS were mediated only by angiotensin II (Ang II). More recently, it has been shown that the role of the RAS in the hydroelectrolytic balance involves other active peptides, such as Ang III, Ang IV and 
angiotensin-(1-7) (Ang-(1-7)) (3,6-10).

\section{Modulation of renal $\mathrm{Na}^{+}$excretion by angiotensin peptides}

In general, the effects of the RAS during extracellular volume regulation involve the modulation of peripheral vascular resistance and renal $\mathrm{Na}^{+}$and water excretion (1). It is well accepted that low concentrations of Ang II cause marked antinatriuresis, whereas higher doses may lead to diuresis and natriuresis (11). Furthermore, it was observed that blockage of Ang II formation increases the capacity of renal $\mathrm{Na}^{+}$excretion in several physiological and pathophysiological conditions in which the RAS is activated $(1,12)$. The antinatriuretic effect of Ang II is often associated with modifications in a) renal blood flow, b) glomerular filtration rate, c) aldosterone synthesis, and d) $\mathrm{Na}^{+}$reabsorption in different segments of the nephron such as proximal and distal tubules. Micropuncture and microperfusion studies performed on rat and rabbit renal proximal tubules demonstrated that Ang II modulates $\mathrm{Na}^{+}$reabsorption in a dose-dependent and biphasic manner $(13,14)$. Physiological doses of Ang II from $1 \mathrm{pM}$ to $100 \mathrm{pM}$ stimulate $\mathrm{Na}^{+}$ reabsorption, whereas higher Ang II concentrations from $0.1 \mu \mathrm{M}$ to $10 \mu \mathrm{M}$ are inhibitory. The stimulatory effect of Ang II on $\mathrm{Na}^{+}$ reabsorption in proximal tubule has been associated with an increase in the activity of the $\mathrm{Na}^{+} / \mathrm{H}^{+}$antiporter in the luminal membrane and of the $\mathrm{Na}^{+} / \mathrm{HCO}_{3}{ }^{-}$cotransporter and $\mathrm{Na}^{+}, \mathrm{K}^{+}$-ATPase in the basolateral membrane (15). On the other hand, the natriuretic effect of Ang II was associated with an increase in renal arterial pressure, which decreases fractional $\mathrm{Na}^{+}$reabsorption in proximal and distal tubules and may cause increases in $\mathrm{Na}^{+}$delivery to the tubules (11). In addition, it was also observed that higher concentrations of Ang II inhibit the $\mathrm{Na}^{+} / \mathrm{H}^{+}$ antiporter and $\mathrm{Na}^{+}, \mathrm{K}^{+}$-ATPase activity in the basolateral membrane of proximal tubule cells $(15,16)$.

Besides Ang II, both Ang IV and Ang-(17) modulate renal $\mathrm{Na}^{+}$excretion (17). Handa et al. (3) observed that Ang IV decreases $\mathrm{Na}^{+}$ reabsorption in proximal tubules by modulating $\mathrm{Na}^{+}, \mathrm{K}^{+}$-ATPase activity. Furthermore, Ang IV potentiates the action of nitric oxide on renal cortical blood flow. It is well established that Ang-(1-7) plays an important role in maintaining body fluid and electrolyte balance and long-term blood pressure homeostasis (18), but the effects of Ang-(17) on renal $\mathrm{Na}^{+}$excretion are controversial (8). In general, it is accepted that Ang-(1-7) is a natriuretic and diuretic compound (19). On the other hand, Baracho et al. (20) observed antidiuretic effects of Ang-(1-7) in water-loaded rats. These data agree with the observation that $10 \mathrm{nM}$ Ang-(1-7) increases water conductivity about four-fold in inner medullary collecting ducts. Garcia and Garvin (21) observed that Ang-(1-7) exhibits a biphasic effect on water and bicarbonate transport in a perfused preparation of straight proximal tubules, similar to that of Ang II. A low concentration (1 pM) of Ang-(1-7) stimulates water transport, while a higher concentration $(10 \mathrm{nM})$ inhibits fluid absorption. This effect has been associated with modulation of the $\mathrm{Na}^{+} / \mathrm{H}^{+}$exchanger. Handa et al. (17) observed that Ang-(1-7) promotes a dose-dependent decrease in $\mathrm{O}_{2}$ consumption over a large range of concentrations $(0.1 \mathrm{nM}$ to $10 \mathrm{nM})$, indicating that Ang-(1-7) also modulates the active transport in proximal tubules.

Taken together, the data indicate that modulation of renal $\mathrm{Na}^{+}$excretion by angiotensin peptides is due, in part, to modifications in $\mathrm{Na}^{+}$reabsorption along the nephron. However, the molecular mechanisms of action of angiotensin peptides are not completely understood. In this short review, we briefly discuss the effects of angiotensin peptides, in particularly Ang II and Ang-(1-7), on the $\mathrm{Na}^{+}$-ATPase activity of renal proximal tubules. 


\section{Modulation of $\mathrm{Na}^{+}$-ATPase of proximal tubule by angiotensin peptides}

Most of the fluid formed during the ultrafiltration process at the glomerular level is reabsorbed in the proximal tubules. This step is modulated by several factors including angiotensin peptides (22). The activity of the ATPases and the process of $\mathrm{Na}^{+}$reabsorption are correlated. There is a prominent expression of $\mathrm{Na}^{+}, \mathrm{K}^{+}$-ATPase in renal proximal tubule cells which provides the energy gradient that supplies the transcellular $\mathrm{Na}^{+}$ reabsorption in this segment of the nephron. In the past decades, a second $\mathrm{Na}^{+}$-ATPase, which is insensitive to ouabain and sensitive to furosemide, was described in several animal tissues (23-28). This $\mathrm{Na}^{+}$-ATPase transports $\mathrm{Na}^{+}$against an electrochemical gradient and is not stimulated by $\mathrm{K}^{+}$. In proximal tubule cells this enzyme is localized in the basolateral membrane and is involved in the extrusion of sodium along with chloride and water (29). Recently, it was shown that $\mathrm{Na}^{+}-$ ATPase is a P-ATPase able to form a phosphorylated intermediate during the catalytic cycle, with a molecular weight of about 100,000 . This phosphorylation is stimulated by furosemide and insensitive to $\mathrm{K}^{+}(30)$.

Although several studies on this enzyme have been published, its physiological role remains to be elucidated. It was first suggested that $\mathrm{Na}^{+}$-ATPase may be involved in cell volume regulation $(27,29)$. The ratio between the $\mathrm{Na}^{+}$-ATPase and $\mathrm{Na}^{+}$, $\mathrm{K}^{+}$-ATPase activities is about $1: 10(23,25$, $26,29)$, compatible with a possible role of this enzyme in the fine tuning of $\mathrm{Na}^{+}$reabsorption in the proximal tubule, whereas $\mathrm{Na}^{+}, \mathrm{K}^{+}$-ATPase may be responsible for most of the $\mathrm{Na}^{+}$reabsorption. Furthermore, our laboratory proposed that the ouabain-insensitive $\mathrm{Na}^{+}$-ATPase is a primary active transport target for compounds involved in the regulation of $\mathrm{Na}^{+}$reabsorption, such as adenosine, Ang II, Ang-(1-7) and bradykinin
$(9,23,25,26)$.

The first evidence of the action of Ang II on the $\mathrm{Na}^{+}$-ATPase activity of proximal tubules was obtained by Munday et al. (31) about 30 years ago. The authors observed that $1 \mathrm{pM}$ Ang II increases the $\mathrm{K}^{+}$- and ouabain-insensitive active $\mathrm{Na}^{+}$transport in slices of rat renal cortex. However, the interpretation of the data given by the authors in order to explain the effect of Ang II on the $\mathrm{Na}^{+}$reabsorption in the proximal tubule was based on the activation of $\mathrm{Na}^{+}, \mathrm{K}^{+}$-ATPase (15). Data obtained in our laboratory show that Ang II and Ang-(1-7), but not Ang III, modulate the $\mathrm{Na}^{+}$-ATPase from porcine cortical proximal tubules (Figure 1).

Ang-(1-7) has a biphasic effect on the $\mathrm{Na}^{+}$-ATPase activity of both cortex homogenate and isolated basolateral membranes from cortical proximal tubules. The maximum stimulatory effect on the enzyme activity is observed at the concentration of $1 \mathrm{nM}$, corresponding to a $68 \%$ increase in the enzyme activity. Similar to Ang-(1-7), Ang II enhances $\mathrm{Na}^{+}$-ATPase activity in a dose-dependent manner. At the concentration of 1 $\mu \mathrm{M}$, Ang II increases the $\mathrm{Na}^{+}$-ATPase activity of basolateral membrane from cortical proximal tubule cells by $139 \%$. These effects of Ang II and Ang-(1-7) are consistent with their effects on fluid reabsorption in proximal tubules as discussed above. So, it is acceptable to propose that $\mathrm{Na}^{+}$-ATPase participates as an important effector mechan-

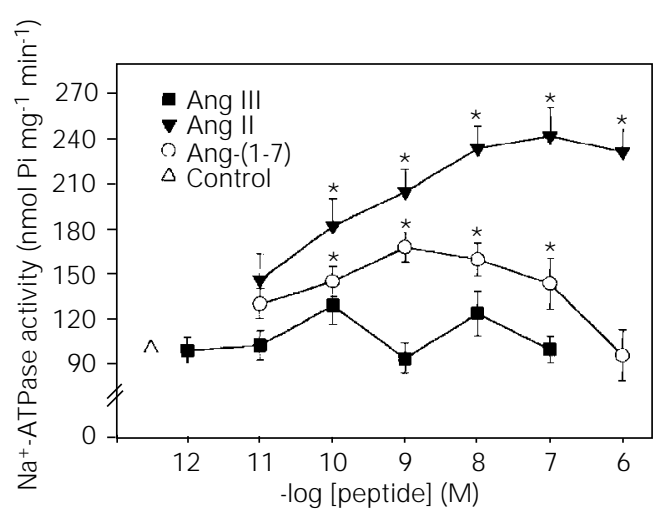

Figure 1. Dependence of $\mathrm{Na}^{+}$ ATPase activity in the isolated basolateral membrane of renal proximal tubules on Ang-(1-7), Ang II and Ang III. ATPase activity was measured as described by Caruso-Neves et al. (9). Each experiment was performed in an independent preparation of basolateral membrane or cortex homogenate. The data were analyzed by two-way analysis of variance (ANOVA), considering the treatments as factors. The significance of the differences was determined by the Bonferroni t-test. Statistical analysis was performed using absolute values and the results are expressed as percentage of the control. $* \mathrm{P}<0.05$ compared to control $(\mathrm{N}=7)$. 
ism in the modulation of fluid reabsorption in the proximal tubule cells by Ang II and Ang-(1-7).

\section{Angiotensin receptors mediate the modulation of $\mathrm{Na}^{+}$-ATPase}

The presence of Ang II receptors in the cortical nephron segments, mainly in the convoluted proximal tubules, was demonstrated in rat kidney by autoradiographic studies using $\mathrm{I}^{125}$-Ang II (32). In the proximal tubule, Ang II receptors are uniformly distributed in both luminal and basolateral membranes $(15,33)$. Burns et al. (34) showed that over $80 \%$ of the Ang II receptors found in the basolateral membrane of proximal tubules from rat and rabbit kidneys are of the $\mathrm{AT}_{1}$ type, with the other $20 \%$ being of the $\mathrm{AT}_{2}$ type. In general, it is accepted that the stimulatory effect of Ang II on proximal tubule $\mathrm{Na}^{+}$reabsorption is mediated by lo-

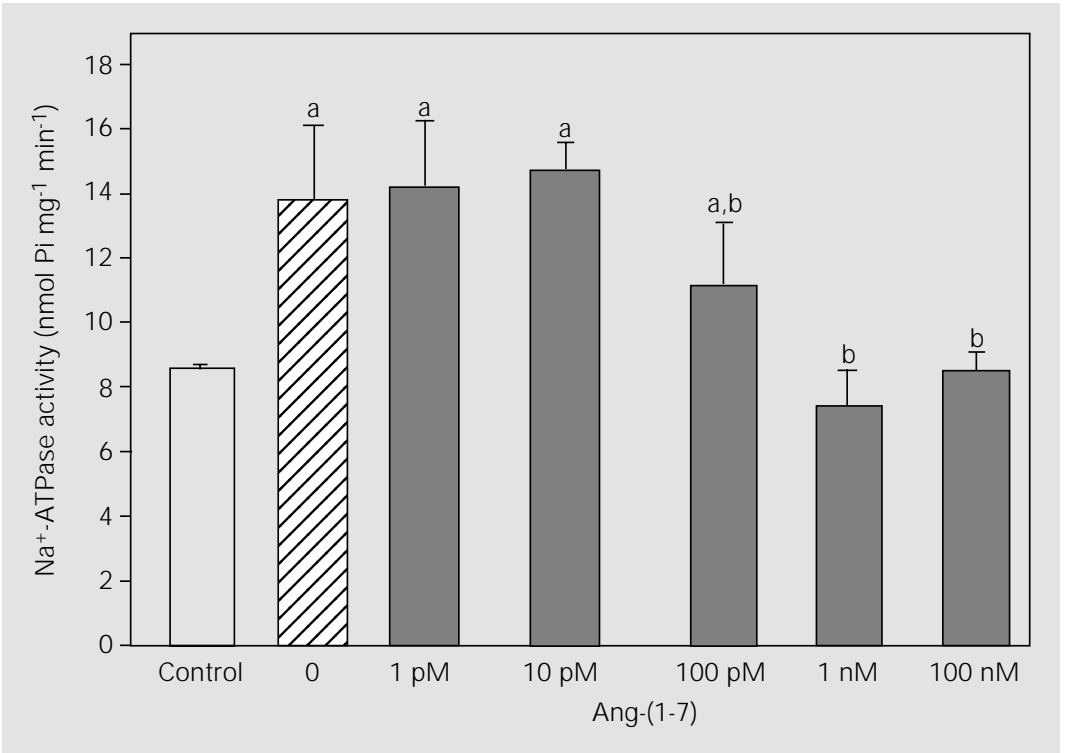

Figure 2. Role of Ang II in the modulation of $\mathrm{Na}^{+}-\mathrm{ATPase}$ activity by Ang-(1-7). Ang-(1-7) concentration was increased from $1 \mathrm{pM}$ to $100 \mathrm{nM}$ in the presence of $10 \mathrm{nM}$ Ang II. ATPase activity was measured as described by Caruso-Neves et al. (9). Before assaying ATPase activity, the enzyme was preincubated for $20 \mathrm{~min}$ in the presence or in the absence of Ang II. The reaction was carried out in the presence of $10 \mathrm{nM}$ Ang II. The data were analyzed as described in Figure 1 . Results are reported as mean $\pm \mathrm{SEM}$. ap $<0.05$ compared to control (in the absence of Ang-(1-7) and Ang II) and $\mathrm{bP}<0.05$ compared to the $\mathrm{Na}^{+}{ }_{-}$ATPase activity in the presence of Ang II $(\mathrm{N}=5)$. sartan-sensitive $\mathrm{AT}_{1}$ receptors located in both luminal and basolateral membranes $(15,35)$.

Actually, the question of which receptor(s) mediate the actions of Ang-(1-7) is still unsettled. It has been reported that the effects of Ang-(1-7) are mediated by different receptors, including $A_{1}$ receptors for Ang II, D-Ala 7 -Ang-(1-7) (A-779)-sensitive receptors, PD123319-sensitive receptors and losartan-sensitive receptors (7). These receptors have a common characteristic, i.e., their sensitivity to saralasin (8). In the kidney, most of the effects of Ang-(1-7) are associated with a losartan-sensitive receptor including the effects of Ang-(1-7) on the proximal tubule $(17,21,36)$. However, other receptor types have been associated with the actions of Ang-(1-7) on the kidney. The stimulatory effect of Ang-(1-7) on water permeability in the inner medullary collecting ducts of rats is blocked by A-779 and also by an $\mathrm{AVP}-\mathrm{V}_{2}$ receptor antagonist $(18,37)$. More recently, Handa (38) observed that Ang-(17) can also bind with high affinity to the $\mathrm{AT}_{4}$ receptor in bovine kidney epithelial cells regulating the MAP kinase/Erk signaling pathway.

The fact that the stimulatory effect of Ang-(1-7) and Ang II on $\mathrm{Na}^{+}$-ATPase activity is completely reversed by saralasin indicates that their actions are mediated by a receptor and are not due to a direct interaction with the enzyme $(9,26)$. Recently, we observed that stimulation of the $\mathrm{Na}^{+}$-ATPase activity of proximal tubules by Ang-(1-7) and Ang II is not modified by PD123319, an antagonist of $\mathrm{AT}_{2}$ receptors, or $\mathrm{A}-779$, but is completely reversed by losartan, a specific antagonist of $\mathrm{AT}_{1}$ receptors $(9,26)$. Taken together, these data suggest that stimulation of the $\mathrm{Na}^{+}$-ATPase activity of proximal tubules by Ang-(1-7) and Ang II is mediated by an $\mathrm{AT}_{1}$ receptor or some other losartansensitive receptor. These data agree with a recent observation that Ang-(1-7) competes with high affinity with Ang II in rat renal cortex (39). However, we showed several 
differences between the effects of Ang II and Ang-(1-7) on $\mathrm{Na}^{+}$-ATPase activity $\left.(9,26): 1\right)$ the effect of Ang II is monophasic, whereas that of Ang-(1-7) is biphasic; 2) the effect of Ang-(1-7) is completely reversed by $0.1 \mathrm{nM}$ losartan, while reversal of the effect of Ang II requires $10 \mathrm{nM}$ losartan, and 3) at high losartan concentration (100 $\mu \mathrm{M})$ Ang-(1-7) stimulates $\mathrm{Na}^{+}$-ATPase in a manner similar to that observed in the absence of Ang II. We postulate that Ang-(1-7) modulates $\mathrm{Na}^{+}$ATPase activity through a different $\mathrm{AT}_{1}$ receptor subtype than Ang II. This possibility of Ang-(1-7) acting at multiple $\mathrm{AT}_{1}$ receptor sites has been suggested previously based on the observation that its actions on renal tubules are either partially or completely blocked by $\mathrm{AT}_{1}$ antagonists, but that it lacks the vasoconstrictive effects characteristic of agonists at $\mathrm{AT}_{1}$ receptor sites $(18,40,41)$. Another possibility is the existence of a losartan-sensitive Ang-(1-7) receptor subtype that is not an $\mathrm{AT}_{1}$ receptor $(7,8)$. This last hypothesis is in accordance with a) the observation that Ang-(1-7) changes the $V_{\max }$ of $\mathrm{Na}^{+}$-ATPase activity but does not change the apparent affinity for $\mathrm{Na}^{+}$, while Ang II increases the apparent affinity for $\mathrm{Na}^{+}$, but does not change the $V_{\max }(9)$, b) losartan has a biphasic effect on $\mathrm{Na}^{+}$-ATPase activity in the presence of Ang-(1-7) and a monophasic behavior in the presence of Ang II $(9,26)$, and c) the maximal effect of Ang II on $\mathrm{Na}^{+}$ATPase activity occurs at $10 \mathrm{nM}$, a ten-fold higher concentration than that required for maximal stimulation with Ang-(1-7) (Figure 1).

\section{References}

1. Harris PJ \& Navar LG (1985). Tubular transport responses to angiotensin. American J ournal of Physiology, 248: F621-F630.

2. Campbell DJ, Lawrence AC, Towrie A, Kladis A \& Valentijn AJ (1991). Differential regulation of angiotensin peptide levels in plasma and kidney of the rat. Hypertension, 18: 763-773.

\section{Interactions between the effects of Ang II and Ang-(1-7) on $\mathrm{Na}^{+}$-ATPase activity}

It has been proposed that Ang-(1-7) may help counteract the actions of Ang II (8). Recently, we observed that Ang-(1-7) progressively reversed the stimulation of the $\mathrm{Na}^{+}$-ATPase activity of proximal tubule by Ang II, with a maximal effect observed at 1 $\mathrm{nM}$ (Figure 2). On the other hand, Ang II does not change the stimulation of $\mathrm{Na}^{+}$ATPase activity by Ang-(1-7) (9). So, under conditions in which Ang II promotes maximal $\mathrm{Na}^{+}$reabsorption in proximal tubules, Ang-(1-7) may down-regulate this process, leading to a fine tuning of the regulatory mechanism of $\mathrm{Na}^{+}$excretion.

\section{Conclusions}

In summary, $\mathrm{Na}^{+}$-ATPase may play an important role in the short-term regulation of $\mathrm{Na}^{+}$reabsorption in the proximal tubule, being the target of angiotensin peptides such as Ang-(1-7) and Ang II. Furthermore, Ang(1-7) could act as an Ang II agonist or antagonist depending on its concentration which represents an important physiological mechanism of extracellular volume regulation.

\section{Acknowledgments}

We thank Dr. Maria Christina Mello for a critical reading of the manuscript.
3. Handa RK, Krebs LT, Harding J W \& Handa SE (1998). Angiotensin IV $\mathrm{AT}_{4}$-receptor system in the rat kidney. American J ournal of Physiology, 274: F290-F299.

4. Inagami T \& Harris RC (1993). Molecular insights into angiotensin II receptor subtypes. News in Physiological Sciences, 8: 215-218.

5. Harris J M \& Gomez RA (1997). Renin- angiotensin system genes in kidney development. Microscopy Research and Technique, 39: 211-221.

6. Santos RAS \& Baracho NCV (1992). Angiotensin-(1-7) is a potent antidiuretic peptide in rats. Brazilian J ournal of Medical and Biological Research, 25: 651-654.

7. Santos RAS, Campagnole-Santos MJ \& Andrade SP (2000). Angiotensin-(1-7): an 
update. Regulatory Peptides, 91: 45-62.

8. Simões-e-Silva AC, Baracho NCV, Passaglio KT \& Santos RAS (1997). Renal actions of angiotensin-(1-7). Brazilian J ournal of Medical and Biological Research, 30: 503-513.

9. Caruso-Neves C, Lara LS, Rangel LBA, Grossi AL \& Lopes AG (2000). Angiotensin (1-7) modulates the ouabain-insensitive $\mathrm{Na}^{+}-$ATPase activity from basolateral membrane of the proximal tubule. Biochimica et Biophysica Acta, 1467: 189197.

10. Neves LAA, Santos RAS, Khosla MC \& Milsted A (2000). Angiotensin-(1-7) regulates the levels of angiotensin II receptor subtype AT1 mRNA differentially in a strain-specific fashion. Regulatory Peptides, 95: 99-107.

11. Olsen ME, Hall JE, Montani J P, Guyton AC, Langford HG \& Cornell JE (1985). Mechanisms of angiotensin II natriuresis and antinatriuresis. American J ournal of Physiology, 249: F299-F307.

12. Burnier $M$, Roch-Ramel $F \&$ Brunner HR (1996). Renal effects of angiotensin II receptor blockage in normotensive subjects. Kidney Intemational, 49: 1787-1790.

13. Ploth DW \& Navar LG (1979). Intrarenal effects of the renin-angiotensin system. Federation Proceedings, 38: 2280-2285.

14. Wang T \& Chan YL (1990). Mechanism of angiotensin II action on proximal tubule transport. J ournal of Pharmacology and Experimental Therapeutics, 252: 689-695.

15. Harris PJ , Hiranyachattada S, Antoine AM, Walker L, Reilly AM \& Eitle E (1996). Regulation of renal tubular sodium transport by angiotensin II and atrial natriuretic factor. Clinical and Experimental Pharmacology and Physiology, 3: S112-S118.

16. Houillier P, Chambrey R, Achard J M, Froissart M, PoggioliJ \& Paillard M (1996). Signaling pathways in the biphasic effect of angiotensin II on apical $\mathrm{Na} / \mathrm{H}$ antiport activity in proximal tubule. Kidney International, 50: 1496-1505.

17. Handa RK, Ferrario CM \& Strandhoy J W (1996). Renal actions of angiotensin-(1-7): in vivo and in vitro studies. American J ournal of Physiology, 270: F141-F147.

18. Santos RAS, Silva ACS, Magaldi AJ, Khosla MC, Cesar KR, Passaglio KT \& Baracho NCV (1996). Evidence for a physiological role of angiotensin-(1-7) in the control of hydroelectrolyte balance. Hypertension, 27: 875-884.

19. DelliPizzi AM, Hilchey SD \& Bell-Quilley CB (1994). Natriuretic action of angiotensin-(1-7). British J ournal of Pharmacology, 111: 1-3.
20. Baracho NVC, Silva ACS, Khosla MC \& Santos RAS (1995). Characterization of the antidiuretic action of angiotensin-(1-7) in water-loaded rats. Hypertension, 6: 1408 (Abstract).

21. Garcia NH \& Garvin J L (1994). Angiotensin 1-7 has a biphasic effect on fluid absorption in the proximal straight tubule. J ournal of the American Society of Nephrology, 5: 1133-1138.

22. Greger R (2000). Physiology of renal sodium transport. American J ournal of Medical Sciences, 319: 51-62.

23. Caruso-Neves C, Francisco-Pedro LG, Souza LP, Chagas C \& Lopes AG (1997). Effect of adenosine on the ouabain-insensitive $\mathrm{Na}^{+}$-ATPase activity from basolateral membrane of the proximal tubule. Biochimica et Biophysica Acta, 1329: 336344.

24. Caruso-Neves C, Meyer-Fernandes J R, Saad-Nehme J, Proverbio F, Marín R \& Lopes AG (1998). Ouabain-insensitive $\mathrm{Na}^{+}$-ATPase activity of Malpighian tubules from Rhodnius prolixus. Comparative Biochemistry and Physiology, 119B: 807-811.

25. Caruso-Neves $C$, Siqueira ASE, Iso-Cohen G \& Lopes AG (1999). Bradykinin modulates the ouabain-insensitive $\mathrm{Na}^{+}$-ATPase activity from basolateral membrane of the proximal tubule. Biochimica et Biophysica Acta, 1431: 483-491.

26. Rangel LBA, Caruso-Neves C, Lara LS, Brasil FL \& Lopes AG (1999). Angiotensin II activates the ouabain-insensitive $\mathrm{Na}^{+}$ATPase from renal proximal tubules through a G-protein. Biochimica et Biophysica Acta, 1416: 309-319.

27. Arenstein IR, Caruso-Neves C, Onuchic LF \& Lopes AG (1995). Mechanisms of cell volume regulation in the proximal segment of the Malpighian tubule of Rhodnius neglectus. J ournal of Membrane Biology, 146: 47-57.

28. Moretti R, Martín M, Proverbio T, Proverbio F \& Marín R (1991). Ouabain-insensitive $\mathrm{Na}^{+}$-ATPase activity in homogenates from different animal tissues. Comparative Biochemistry and Physiology, 98B: 623-626.

29. Proverbio F, Marín R \& Proverbio T (1989). The "second" sodium pump and cell volume. Current Topics in Membranes and Transport, 34: 105-119.

30. Marín R, Proverbio F, Proverbio $T$, Ventrella N, Pagliarane A, Trombette F, Trigari G \& Borgatti AR (1999). Phosphorylated intermediate associated with ouabain-insensitive $\mathrm{Na}^{+}$-ATPase. Satellite Symposium "Cell Homeostasis: Channels and Transporters" in XVth International Con- gress of Nephrology and XIth Latin-American Congress of Nephrology, May 8-10, 1999, Guarujá, SP, 9.

31. Munday KA, Parsons BJ \& Poat J A (1971). The effect of angiotensin on cation transport by rat kidney cortex slices. J ournal of Physiology, 215: 269-282.

32. Mujais SK, Kauffman S \& Katz Al (1986). Angiotensin II binding sites in individual segments of the rat nephron. J ournal of Clinical Investigation, 77: 315-318.

33. Brown GP \& Douglas J G (1982). Angiotensin II binding sites on isolated rat renal brush border membranes. Endocrinology, 111: 1830-1836.

34. Burns KD, Inagami T \& Harris RC (1993). Cloning of a rabbit cortex $\mathrm{AT}_{1}$ angiotensin II receptor that is present in proximal tubule epithelium. American J ournal of Physiology, 264: F645-F654.

35. Hiranyachattada S \& Harris PJ (1996) Modulation by locally produced luminal angiotensin II of proximal tubular sodium reabsorption via an $\mathrm{AT}_{1}$ receptor. British J ournal of Pharmacology, 119: 617-618.

36. Chappell MC, Diz DI, Yunis C \& Ferrario CM (1998). Differential actions of angiotensin-(1-7) in the kidney. Kidney International, 54: S3-S6.

37. Cesar KR, Santos RAS, Khosla MC \& Magaldi AJ (1995). Angiotensin-(1-7) increases water reabsorption in rat inner medullary collecting duct. Hypertension, 25: 1408 (Abstract).

38. Handa RK (2000). Binding and signaling of angiotensin-(1-7) in bovine kidney epithelial cells involved the $\mathrm{AT}_{4}$ receptor. Peptides, 21: 729-736.

39. Gironacci M M, Coba MP \& Pena C (1999). Angiotensin-(1-7) binds at the type 1 angiotensin II receptors in rat renal cortex. Regulatory Peptides, 84: 51-54.

40. Santos RAS, Campagnole-Santos MJ Baracho NCV, Fontes MAP, Silva LCS, Neves LAA, Oliveira DR, Caligiome SM, Rodrigues ARV, Gropen C, Carvalho WS, Simões-e-Silva AC \& Khosla MC (1994). Characterization of a new angiotensin antagonist selective for angiotensin-(1-7): Evidence that the actions of angiotensin(1-7) are mediated by specific angiotensin receptors. Brain Research Bulletin, 35: 293-298.

41. Burnier $M$, Pechere-Bertschi A, Nuss berger J , Waeber B \& Brunner HR (1995). Studies of the renal effects of angiotensin II receptor blockade: The confounding factor of the acute water loading on the action of vasoactive systems. American J ournal of Kidney Diseases, 26: 108-115. 